\title{
Commentary - Easternization of the world
}

Introduction

"Oh, East is East, and West is West, and never the twain shall meet," so wrote Joseph Rudyard Kipling in his Ballad of East and West. Kipling's ballad created a lot of interest as well as criticism in the early nineteen hundreds. He was born in India in 1865 to a Scottish family who settled in India. In his early childhood, he experienced the cultural differences between the East and the West. He admired both cultures even though some critics labeled it as a White colonial with racial prejudices.

Kipling is not only dead, but he is also wrong. Last century (20th) was about Westernization of the world. More accurately, it was all about modernization, mainly due to industrialization and the shift from the agriculture-based economy to a factory-based economy. The industrial age brought breakthrough innovations such as automobiles, radio, telephone, appliances, television, and today the Internet and social media.

As the economy shifted from the agriculture sector to the industrial sector, consumption became contemporary and conspicuous. Unbranded consumption became branded consumption for products such as soaps, shampoos and toothpaste. Similarly, unorganized retailing gave way to organized retailing, including supermarkets and shopping malls.

Finally, the British and other colonial powers had aggressive expansion all over the world either to secure industrial raw materials or to develop markets of their colonies through education, infrastructure investments, and distribution ecosystem of trade, commerce and manufacturing in their colonies. Modernization meant giving up traditional methods of farming and household work. It also included changing the habits of food, shelter and clothing. In Asia, for example, Japanese women gave up their kimono and adopted the Western outfits of blouse and skirt so that they can work in factories. This was followed in Taiwan, Philippines, South Korea, and eventually everywhere. In all cases, modernity replaces the traditions of thousands of years. Fast food franchises such as McDonald's, KFC and Starbucks replaced homestyle cooking.

\section{Easternization of the world}

While the 20th century witnessed Westernization (modernization) of the world, the 21st century is experiencing the Easternization of the world. In Chindia Rising, Sheth observed that the Easternization of the world had already begun in the 1990s with the rise of China and India. There are at least four forces that are driving the Easternization of the world. The first and very critical factor is the rapidly aging and affluent Western cultures and economies. For example, in the US, more than 10,000 people are reaching the retirement age of 65 each day, and this will continue for decades.

It is natural for the aging population to be concerned with health preservation as well as wealth preservation. Also, people are searching for the meaning of life. In terms of Maslow's hierarchy of needs, people in advanced countries are reaching a stage of self-actualization. The philosophy and practices of Eastern wisdom of spirituality, looking within yourself for happiness, meditation and yoga are, therefore, the first wave of Easternization.

While Westernization was all about material possessions and the Western lifestyles of indulgence, the Eastern philosophy advocates detachment and, therefore, non-possession of wealth. Ownership creates anxiety and stress, and decreases inner happiness. The three

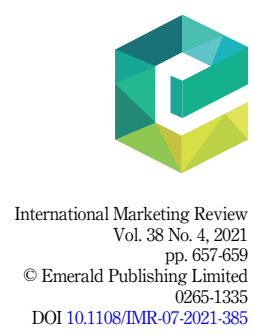


IMR

38,4

tenets of Jainism and Buddhism are absolute nonviolence, tolerance for multiple perspectives and renunciation of possessions. Practicing them in day-to-day life are essential to achieving happiness. There is also growing interested in Eastern medicines and medical practices. These include Chinese medicine, Indian Ayurveda as well as acupressure and acupuncture techniques. There is also a growing concern about the long-term side effects of Western medicine. This has also raised interest in Eastern traditions of medicine and medical practices such as yoga and tai chi.

A second major area of the Easternization of the world is environmental sustainability. The principles of nonviolence are extended to all living organisms, including animals, birds and marine life. This has led to the growth of vegetarianism and veganism. Today, more people in the Western world, both young and old, believe that consumption of animal-based foods is harmful to the self, the planet, as well as the community. A plant-based diet is rapidly adopted all over the world, resulting in substitution for meat and poultry. Finally, Eastern philosophy and wisdom encourages conservation by mindful consumption and recycling, reducing and reusing durable products such as automobiles, homes, appliances and clothing.

A third major factor for rapid diffusion of Easternization is the influence of social media such as Facebook, Instagram, WhatsApp and YouTube. User-generated content today is multicultural and has cross-cultural influences. It is a borderless world, especially among young people. Information influence and imitation are increasingly going viral and amplified by traditional news and entertainment media. Through social media, there is a significant influence on arts, music and culture as well as cuisines and beverages.

Finally, with the rise of nationalism in emerging markets such as China and India, many scholars in management science and liberal arts are going back to their roots and bringing back the old wisdom to the contemporary world. For example, several books have been written on what today's management can learn from the epic Indian mythologies (Ramanaya and Mahabharat) the ethical and moral dilemmas are encountered when you are in power. Similarly, great Eastern thinkers, including Confucius and Tao's doctrine of compassion, frugality and humility are rediscovered and contextualized to the contemporary modern issues in all spheres of life.

\section{Implications for marketing}

At a macrolevel, there are three significant implications for marketing practice and discipline.

First, can marketing become a positive force for a better world? It seems that wisdom of east Asia (happiness, inner peace and harmony, the yin-yang philosophy), as well as a frugal and simple life, will become valuable tools and practices to influence sustainability consumption.

Second, future product innovations and improvements can be designed with Eastern philosophy embedded upfront in the research and development. This can range from designing homes, appliances and automobiles. They can also be embedded in medical discoveries and breakthroughs as well as necessities of life.

Finally, brands have meanings for consumers. Through brand consumption, can the consumer believe they are contributing not only to their well-being, but also the well-being of the planet and the community? A recent linkage of purpose in brands is a good start, but it can realize the even greater impact and loyalty if anchored to Eastern philosophy. Recent advertisements by Unilever for all their products are a good start.

\section{Conclusion}

While the 20th century witnessed the Westernization of the world, the 21st century will witness the Easternization of the world. However, unlike the Westernization, which focused 
on material possessions and conspicuous consumption, the Easternization will focus on spirituality, meditation and yoga. The main reason is the aging of the affluent nations as well as reaching a stage of self-actualization. Easternization of the world will be faster due to social media and a genuine search for a purposeful life.

Jagdish N. Sheth

Department of Marketing, Goizueta Business School, Emory University, Atlanta, Georgia, USA

\begin{abstract}
About the authors
Jagdish N. Sheth is Charles H. Kellstadt Professor of Business in the Goizueta Business School at Emory University. He is globally known for his scholarly contributions in consumer behavior, relationship marketing, competitive strategy and geopolitical analysis. Professor Sheth has over 50 years of combined experience in teaching and research at the University of Southern California, the University of Illinois at Urbana-Champaign, Columbia University, MIT, and Emory University. He is an expert on consumer behavior, impact of technology on society and globalization of competition. Professor Sheth has been advisor to numerous corporations all over the world. He has authored or coauthored more than three hundred papers and several books.
\end{abstract}

